\title{
Обонятелни теории и количествена оценка на обонянието
}

\author{
Н. Цаков, Д. Димов \\ УМБАЛ "Царица Йоанна - ИСУЛ" - София
}

\begin{abstract}
ъвременният ниськ статус на обонянието е резултат от преоценката на сетивата от философите и учените на XVIII и XIX век. Обонянието било разглеждано като нискоразрядно, примитивно, дивашко и животинско, тьй като то е от тези сетива, при които контролът е загубен. Всяко вдишване изпраща върху рецепторите на носа въздух, натоварен с молекули, носещи потенциала, неприятна и нецензурирана информация към мозъка. Настоящата разработка има за цел да представи комплексноста на някои обонятелни теории, като успоредно с това да покаже и опитите за цялостна оценка на обонятелните способности на изследваните лица (това най-често са пациенти с различна степен на нарушение на обонянието) в България.
\end{abstract}

\section{Обонятелни теории}

C течение на годините са предложени множество теории, които свързват обонятелните свойства на веществата с тяхната молекулярна структура. Сега ще разгледаме две от най-известните от тях, като добавим трета, включваща директното участие на някои невротрансмитери или техните хидролизати при свързването на обонятелните молекули с обонятелния рецепторен протеин.

\section{- Стерична теория на обонянието}

През 1946 г. бъдещият нобелов лауреат Линус Паулинг (Pauling, L., 1994, 9) постулира, че специфичните миризми се дължат на молекулярната форма и размер на химическите вещества. По подобна аналогия, в кни- 
гата си „Молекулярни основи на обонянието“ Джон Амур (Amoore, J.E., 1970, 2) разширява идеята на „Стерична теория на обонянието“ предложена първоначално от Р. В. Монкриф през 1949 г. (Moncrieff, R.W., 1949, 8), която твърди, че летливите химически молекули предизвикват обонятелно усещане, когато съвпаднат комплементарно върху дадени рецепторни места, разположени по обонятелната нервна система. Този подход на „ключ в ключалка“ произлиза от достиженията върху ензимната кинетика по това време. Амур предполага наличието на първични одорифери (етерни, камфорни, мускусни, флорални, ментови и прутридни). Подобията на молекулярните размери и форми при различните одорифери са били сравнявани чрез направени на ръка молекулярни модели и физични измервания на обеми (поради липса на компютьрна изчислителна техника тогава).

Стеричната теория добре пасва на идеята, че обонятелните рецепторни протеини приемат само някои дадени одоранти върху специфични рецепторни места. След това рецепторьт се активира (чрез конформационна деформация?) и се куплира c G-белтък, с което започва сигналната трансдукционна каскада.

\section{- Вибрационна теория на обонянието}

Дисон (Dyson, G. M., 1938, 3) през 1938 г. изказва предположението, че инфрачервеният резонанс, използван за измерване на молекулярни обеми, може да се свърже с обонянието. В средата на 50те години тази идея е била популяризирана от Р.X. Райт във връзка с популяризирането на инфрачервените спектрофотометри (Wright, R. H., 1986, 15). През 60-те и началото на 70-те години са се водили ожесточени дебати относно правотата на отделните теории. Към средата на 70-те години теорията на Райт се проваля на един важен тест. Оптичните енантиомери на различно миришещите menthol (Leffingwell, J. C., 6) и carvone (Langenau, E. E., 1968, 5), притежават идентични инфрачервени спектри.

Спектроскопска теория на индуцираното от вибрации преминаване на електрони. До публикуването на интересната дисертация на Тюрин (Turin, L., 1996, 13) през 1996 г. вибрационната теория била покрита под пльтни облаци. Тюрин обаче се опитал да осигури детайлизиран и достоверен механизъм за биологична трансдукция на молекулярни вибрации, който кара рецепторните протеини да действат като „биологичен спектроскоп“. Това, което се предлага, се нарича „нееластично преминаване на електрони“. Достатьчно е да споменем, че рецепторьт се задейства от даден одорант в присъствието на NADPH (ß-никотинамид аденин динуклеотид фосфат, редуциран), който се образува след ензиматичната редукция на ß-никотинамид аденин динуклеотид фосфат (NADP). NADPH е широко разпространен в живата материя и действа като ензимен кофактор. ß-NADPH е продукт на пентозофосфатния път - мултифункционална система, осигуряваща редукционна енергия под формата на $ß$-никотинамид аденин динуклеотид фосфат, редуциран. ß-NADPH трансферира водороден катион и два електрона към окислени прекурсори в редукционните реакции на биосинтезата. По този начин ß-NADPH се обменя в цикъл между реакции на катаболизъм и синтез, като осигурява редукционна енергия по същия начин, по който АТФ служи като преносител на енергия (Wood, W. B., 2002, 14).

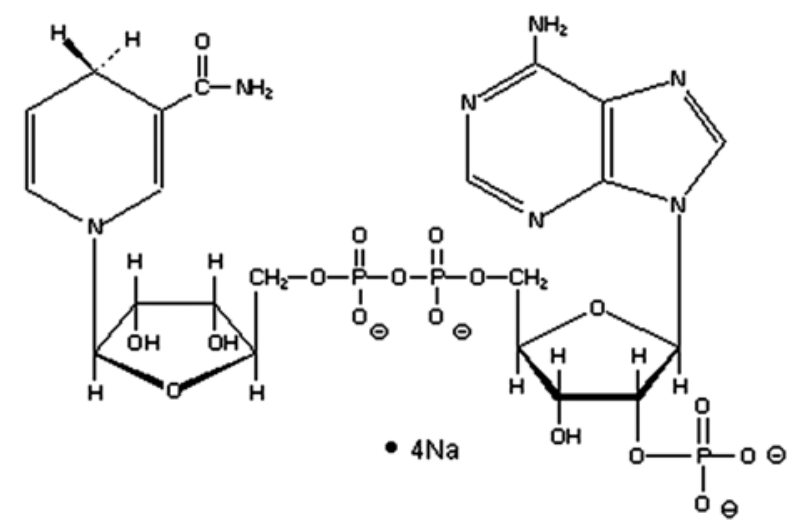

Фиг. 1. NADPH

Доколкото теорията на Тюрин твърди, че рецепторьт функционира като „NADPH диафораза“ би следвало да се очакват високи нива на диафоразна активност в обонятелните рецепторни неврони (Zhao, H., S. Firestein, C. A. Greer, 1994, 16). За да възникне подобен електронен трансфер, Тюрин, базирайки се на молекулярното моделиране, предполага, че свързващите места за цинк са налице и в белтька на обонятелния рецептор, и в G-протеините. Възможната връзка между цинка и обонянието, електронния поток и G-протеините се опира на неговата способност да формира мостове между белтъците. Наличието на цинк в ензими, пренасящи електрони, като напр. алкохолдехидрогеназа и наличието му в редокс-активната аминокиселина цистеин, служеща като цинк свързващ мотив в обонятелния рецептор, ни насочва за възможна връзка между електронен поток и G-протеиновата трансдукция. Представете си, че цинк свързващият мотив в обонятелния рецептор е отговорен за осъществяването на връзката с обонятелния G-протеин и че това свързване е базирано на фор- 
мирането на дисулфиден мост между рецептора и G-протеина. Би следвало да се очаква, че върху G-обонятелния белтьк ще трябва да се намира другата половина на конкордантното място за цинка, като напр. два хистидина и цистеин в непосредствена близост един до друг. Проучване върху аминокиселинната последователност на обонятелния G-протеин открива мотива (His-Tyr-CysTyr-Pro-His). Този мотив има всички реквизити на свързването. Той е експозиран по повърхността на обонятелния G-протеин и за него се знае, че взаимодейства с G-протеин куплирани рецептори. Подобен механизъм на циклична редукция и окисление на дисулфидни мостове вече се предполага и за адренергичните рецептори (Kuhl, 1985, 4.). Той включва прекръстосване на G-протеин с рецептора посредством S-S мост, който след това се редуцира от свързването на редокс-активен катехоламин за рецептора, освобождавайки по този начин G-протеина. Тюрин предполага, че подобен механизъм вероятно е отговорен и за обонянието.

Преминаването на електрони в общи линии представлява трансфер на електрони по «гръбнака» на белтъчната молекула. Ето как би следвало да стане това:

Когато свързаващото място на (обонятелния) рецептор е празно, електроните не са в състояние да преминат през свързващото място, тъй като липсват подходящи свободни енергийни нива. Дисулфидният мост между рецептора и свързания с него G-протеин остава в окислено състояние. Когато даден одорант (представен под формата на еластичен дипол) заеме мястото на свързване, електрони могат да загубят енергията си по време на прехода посредством възбуждане на собствените си вибрации. Това се случва само тогава, когато енергията от вибрациите се изравни с енергийната разлика между запълнените и свободните нива. Тогава електроните протичат през белтька и редуцират дисулфидния мост чрез цинков йон, освобождавайки по този начин G-протеина за следващите стъпки на сигналната каскада.

Ако между източника на електрон и мястото, където този електрон, «потьва» застане молекула и тази молекула вибрира (приемаме енергията на вибрацията за Е), може да възникне индиректно преминаване през допълнителен канал, ако е налице по-високо енергийно ниво в източника на електрон. След преминаването молекулата ще притежава вибрационна енергия, по-висока от Е. С други думи, преминаването става само тогава, когато вибрационната енергия на молекулата съвпадне с енергийната разлика между нивото на донора и енергийното ниво на акцептора. Рецепторът следо- вателно действа подобно на спектрометър, който е в състояние да засече единична, добре дефинирана енергия Е. Ако разликата между енергиите на нивата на донора и акцептора е достатъчно голяма, поток от електрони преминава през ,устройството“ само ако разликата е заета от молекула, която е с подходяща вибрационна енергия.

Макар и теорията на Тюрин да не е валидирана официално, тя изглежда правдоподобна. Но дори и да бъде потвърдена, това не означава задължително, че „Стеричната теория“ ще загуби значение.

\section{Съвременни концепции за обонянието}

\section{- Комбинационни процеси в обонятелната интерпретация}

През март 1999 г. Линда Бук и Бетина Малник от Медицинския университет в Харвард и Янузо Хироно и Такаки Сато от Изследователския институт по биоелектроника в Амагасаки, Япония (Malnic, B., J. Hirono, T. Sato, L. B. Buck, 1999, 7), изглежда че разкриха мистерията около това как носът интерпретира изобилието от различни аромати.

Обонянието на бозайниците се базира на комбинационен подход при разпознаването и обработката на обонятелната информация. Вместо да имаме индивидуален обонятелен рецептор за всяка отделна специфична миризма, обонятелната система използва ,азбука“ от рецептори за създаването на специфичен обонятелен отговор в невроните на мозъка. Както в езика (или в музиката), обонятелната система използва комбинации от рецептори (аналози на буквите или музикалните ноти), с което значително редуцира набора от рецепторни типове, препредаващи богатия спектьр от миризми.

Както 4-те нуклеотида на генетичния код (аденин, цитозин, гуанин и тимин) позволяват кодирането на почти неограничен брой от генетични комбинации, откритията на Бук и сътр. осигуриха първото подтвърждение, че нервите, участващи в обонятелната система на бозайниците, също използват комбинационен подход.

Когато дадена мирзма възбуди обонятелен неврон, сигналът преминава по невроналния аксон и се препредава на невроните в обонятелната луковица. Тази структура отговаря за преработката и предаването на обонятелния усет. От обонятелната луковица обонятелните сигнали се препредават към мозъчните кори на двете хемисфери - мястото на осъзнаване на обонятелната информация, и към лимбичната система, която генерира емоционални усещания.

В докладваните изследвания са били използвани индивидуални миши неврони, изложени на ралич- 
ни одоранти. Изполвайки техника, наречена калциево изобразяване, изследователите откриват коя нервна клетка се е стимулирала от дадена миризма. (При свързването на одоранта с обонятелния рецептор се отваря калциев канал и калциеви йони нахлуват в неврона. Това генерира електрически товар, който потича по аксона под формата на нервен импулс. Калциевото изобразяване измерва този калциев инфлукс). Използвайки тази техника, беше показано, че: (1) отделните рецептори разпознават множество одоранти; (2) даден одорант обикновено се разпознава от множество рецептори и (3) различните одоранти се разпознават благодарение на комбинациите от кодиращи схеми, нужни за идентификация на миризмите. Това обясни как около 1000 рецептора могат да опишат десетки хиляди различни миризми. Бук и нейните колеги демонстрираха също така, че дори слаби промени в химическата структура активират различни комбинации от рецептори. Ето защо октанольт има приятна миризма, но подобното съединение октаноева киселина има миризма на пот. Откри се и че големи количества от даден химикал се свързват за по-голям брой различни рецептори, в сравнение с малки количества от същото вещество. Това наблюдение би могло да обясни защо голямо количество от химическото вещество индол има прутридна миризма, докато следи от същия химикал притежават флорален мирис (на цветя).

\section{- Вомероназален орган при хората}

От 18-ти век насам вомероназален орган е бил установяван при човешки фетуси, а също така спорадично е бил описван и при възрастни, въпреки че мнозина приемат тези твърдения за недоказуеми. Повечето изследователска работа върху вомероназалния орган е била извършвана върху гризачи, змии и насекоми - същества, при които феромоните играят важна роля в комуникацията, привличането и репродукцията. Наличието на вомероназален орган (ако въобще съществува) при хора е тема на дебати. Наскоро обаче Савич и сътр. показаха активиране на хипоталамуса (преоптични и вентромедиални ядра) при жени, подушили андроген-подобни компоненти. При мъжете подобна възбуда на хипоталамуса (този път: паравентрикуларни и дорзомедиални ядра) била установена при помирисване на естрогено-подобна субстанция. Тази полово обусловена дисоциация на хипоталамично активиране подсказва за наличието на потенциален физиологичен субстрат на полово диференцирания поведенчески отговор при хората (Savic, I., H. Berglund, B. Gulyas, P. Roland, 2001, 12). Дали това ще оси- гури индиректно (или директно) доказателство за съществуването на дискриминация, подобна на тази осъществявана от вомероназалния орган, предстои да видим в бъдеще.

Наскоро Момбертс, Греер и сътр. ( Rodriguez, I., C. A. Greer, M. Y. Mok, P. Mombaerts, 2000, 10) показаха, че в човешкия геном се съдържа поне един ген, установен в епителната покривка на носа, който точно наподобява фамилия на миши феромонни рецептори - гени, които са отговорни за откриването на химикали, непритежаващи миризма, каквито всъщност са феромоните. „До публикуването на това изследване““, казва Греер, „имаше консенсус, че хората не притежават рецептори, принадлежащи към тази генна фамилия. Сега вече имаме широко отворена врата за преосмисляне на функционалната рганизация на човешката обонятелна система“. Момбертс не очертава възможност за откриване на цяла поредица от феромонни рецептори в бъдеще, но е сигурен, че ще открие поне още един-два.

\section{- Енантиомерна специфичност на обонятел- ната луковица}

Добре известен факт е, че при хора някои специфични химически енантиомери могат да бъдат различени по миризмата. Такива вещества са (имената са по номенклатурата IUPAC): carvone, menthol, limonene, linalool, alpha-terpineol, citronellol, 7hydroxy citronellol, 1-octen-3-ol, delta-decalactone, gamma-decalactone, 2-methyl-4-propyl-1,3-oxathiane, p-menthene-8-thiol, nootakatone, patchoulol, alpha-damascone, alpha-ionone, 3-mercapto-2-methylpentanol, (E)- \& (Z)-nerolidol, alpha-phellandrene, 2-ethylhexanolat, cis-rose oxide, nerol oxide, ethyl 2methylbutyrate, methyl 2-methylbutyrate, жасминов лактон, ethyl 2-охо-3-methylpentanoate, 2-methylbutyric acid, 2,4,6-trimethyl-4-phenyl-1,3-dioxane, methyl dihydrojasmonate, 1-(2',2',6'-trimethyl-1'cyclohexyl)-3-hexanol, 2-ethyl-4,4-dimethyl-1-cyclohexanone, 2,5,6-trimethyl-2-heptanol, 2-methyl-4(2',2',3' -trimethyl-3' -cyclopenten-1'-yl)-4-pentenenitrile, the 2-methyl-4-(2',2',3'-trimethyl-3'-cyclopenten-1'-yl)-4-penten-1-оли, the 3,3-dimethyl5-(2',2', 3' -trimethyl-3' -cyclopenten-1' -yl)-4-pen ten-2-оли, the 5,6,7,8-tetrahydro-3,5,5,6,7,8,8-heptamethyl-2-naphthalenecarbaldehyd, the 5,6,7,8-tetrahydro-3,5,5,6,7,8,8-heptamethyl-2-naphthalenecarbonitril, 2-ethyl-4-(2,2,3-trimethylcyclopent-3-en-1yl)-2-buten-1-ol, the ambroxid. Наскоро Рубин и Кац публикуваха явни доказателства за това, че плъховете са в състояние да дискриминират огромно разнообразие от енантиомери, които са неразличими за хората (Rubin, Katz, 2001, 11). Наскоро 
бе разкрита и енантиоселективността на пчелите, като се установи, че техните дискриминационни способности се приближават до тези на хората.

\section{Количествена оценка на обонятелните способности}

Високата комплектност на гореизложените данни поставя още по-висока летва пред клиничното изследване на обонянието, което за РБългария се извършва по сертифицирания за страната метод на проф. Димов, използващ специален уред - олфактометъра на Димов-Райков.

Основният принцип, на който е построен олфактометърът на Димов-Райков, е импулсивният метод на Елсберг и Леви. Той се състои от принудително подаване на точно определен обем ароматичен газ в носа на изследваното лице. По такъв начин се определя относителният праг на обонятелната чувствителност. Основната идея, залегнала в конструирането на този олфактометър, е едновременното изследване на двете основни функции на обонятелния анализатор - количествена и качествена оценка на едно и също ароматично вещество. Това значи, че след установяване на относителния праг на възприемане на ароматичното вещество да се определи и способността за идентифицирането им, т.е. обонятелната спектрограма. По този начин се съди както за състоянието на периферната рецепторна част на обонятелния анализатор, която взема най-голямо участие при определянето на относителния праг, така и за централните обонятелни субстрати, където се осъществява диференцировката на ароматичните вещества. При съществуващите олфактометри, чрез които се установява обонятелният праг към едно ароматично вещество (прим. n-butanon), определянето на спектрограмата става с поднасяне на одорифера на изследваното лице и по такъв начин прагът на различаване (определяне) не може да се определи и изследването на обонянието става едностранчиво - или само количествено, или само качествено. Това от своя страна води до изгубване на връзката и взаимозависимостта на двете основни функции на обонятелния анализатор. Като имаме предвид специфичния праг на възприемане на ароматичните вещества, т.е. индивидуалната чувствителност към определено вещество и липса на такава към друга (наличие на аносмична зона), ние бихме дали погрешно заключение за състоянието на обонятелния анализатор, ако правим изследване на относителния праг към едно ароматично вещество. Впрочем, това е и един от недостатыците на повечето олфактометри, с които се изследва общият (относителният) праг чрез едно ароматично вещество. Вземайки предвид тези съображения, създателите на този олфактометър поставят няколко ароматични вещества с различна прагова концентрация, за да дадат по-пълна представа за функцията на обонятелния орган. Още повече че според съвременните схващания за обонянието, освен изключителната роля, която ce пада на fila olfactoria, известно значение имат обонятелните усещания, които се провеждат чрез n. trigeminus и $n$. glossopharyngeus. Ето защо, за да бъде пълно изследването на обонянието, освен чисто обонятелните възприятия се изследват тактилните компоненти (n. trigeminus, който придава остротата на обонянието) и вкусовите компоненти (n. glossopharyngeus, по който се провежда „вкусовото обоняние“). По такъв начин изследването на обонянието ще бъде адекватно на физиологичното отреагиране на обонятелния анализатор при естествените условия на възприемане. Всичко това е наложило включването в олфактометьра на ДимовРайков на такива ароматични вещества, които избирателно да се възприемат от трите нерва, участващи в акта на обонянието - fila olfactoria, $n$. trigeminus и n. glossopharyngeus.

\section{Ароматични вещества, включени в олфактометьра на Димов-Райков}

Ароматичните вещества, включени в олфактометъра на Димов-Райков отговарят на следните изисквания: (1) стабилност, тъй като обикновено одориферите представляват неустойчиви вещества; (2) липса на голяма абсорбируемост от околните предмети; (3) точно определено качество (миризма) и интензитет; (4) да не бъдат вредни за човека; (6) ароматичните вещества са подбрани по такъв начин, че да не се получат явления на маскировка и адаптация; (7) използваните одоранти притежават аромати, които са познати на всички хора от всички възрасти. Подбрани са както приятни, така и неприятни миризми, което има значение при определянето на качествените (централни) разстройства на обонянието.

а. Терпениол. Терпениолът (молекулно тегло $154.25 \mathrm{~g} / \mathrm{mol})$ е естествен монотерпенов алкохол, който може да се изолира от най-различни естествени прекурсори, като напр. дървесни масла (найвече бор).

Има три изомера алфа, бета и гама терпениол, като последните два се различават по мястото на двойната връзка. Терпениолът обичайно представлява смес от трите изомера, като в най-голям процент е алфа-терпениолът. Терпениольт притежава приятна миризма и е честа съставка в парфюми, козметични продукти и аромати. 
б. Гераниол. Гераниолът представлява съединение на монотерпеноид с алкохол (молекулно тегло $154.25 \mathrm{~g} / \mathrm{mol}$ ). Той е основната съставка в розовото масло. Представлява бледожълта водонеразтворима маслена течност. Има аромат на роза и често се използва в парфюмерийната индустрия. Участва в ароматите на праскова, боровинка, грейпфрут, червена ябълка, слива, портокал, ананас и диня. Изследователи доказаха свойствата на гераниола като ефективен репелент срещу комари, но, от друга страна, гераниольт е в състояние да привлича пчели, тъй като той се продуцира от специални жлези на медоносната пчела и тя го използва за маркиране на богати на нектар цветя. Въпреки че гераниольт се открива естествено в добре узрял и изсушен тютюн, той влиза в 599-те вещества, които тютюнопроизводителите добавят в тютюна за подобряване на неговите органолептични качества.

в. Цитрал. Цитральт (молекулно тегло 152.24 g/ $\mathrm{mol}$ ) или още: 3,7-диметил-2,6-октадиенал (лемонал) представлява двойка терпеноиди с молекулярна формула $\mathrm{C}_{10} \mathrm{H}_{16} \mathrm{O}$. Двата компонента представляват изомери, свързани с двойна връзка. Е-изомерът е известен като цитрал A, a Z-изомерът като цитрал Б. Цитрал А притежава силна лимонова миризма, докато цитрал Б също има лимонов мирис, но по-сладникав. Поради тези си свойства цитральт също се използва в парфюмерийната индустрия. Там цитральт се добавя към лимоново масло за засилване на аромата му. Има също така силно изявени противомикробни), а при насекомите има феромонни ефекти. Цитральт се изполва при синтеза на витамин А и в средства, маскиращи тютюнев дим.

г. Ментол. Съществуват доказателства, че ментольт (молекулно тегло $156.27 \mathrm{~g} / \mathrm{mol}^{-1}$ ) е известен на японците от преди 2000 години. Западът го открива едва през 1771 г., когато бива изолиран от Йеронимус Давид Гаубиус.

Ментольт представлява органично вещество, което се получава или синтетично, или се извлича от ментата. Представлява восъкоподобна, бяла кристална субстанция, която е твърда при стайна температура. Основната форма, под която ментольт се открива в природата, е (-)-ментол. Ментольт притежава противовъзпалителни и анестетични свойства. Използва се широко като лекарство при леки възпаления на гърлото. Използва се като антипруригинозен агент (противосьрбежно действие), продава се под формата на носен инхалант за отпушване на носа. Ментольт сьщо така участва в множество препарати за орална хигиена (вода за уста) и не на последно място - в парфюмерийната и хранително-вкусовата промишленост. д. Оцетна киселина. Оцетната киселина (молекулно тегло $60.05 \mathrm{~g} / \mathrm{mol}$ ) представлява органично съединение, което дава характерния аромат и кисел вкус на оцета. Структурната формула на оцетната киселина е $\mathrm{CH}_{3} \mathrm{COOH}$. Чистата обезводнена киселина (ледена оцетна киселина) представлява безцветна хигроскопична течност, която замръзва под $16,7^{\circ} \mathrm{C}$. Оцетната киселина представлява корозивен агент и нейните изпарения предизвикват дразнене в очите, носа, гърлото и трахеята. Представлява важен компонент в индустриалната химия.

\section{Работа на олфактометьра на Димов-Райков}

Чрез специална ръкохватка и механично устройство буталото на един въздушен цилиндър се изтегля от пьрвоначалното си положение (до Рубеновата клапа) до желания обем и в цилиндьра влиза въздух през долния отвор на клапата. Чрез пусков бутон електромагнит освобождава натегнатата пружина на буталото и то с равномерна скорост изтласква въздуха през отвор на клапата към филтьр с активен въглен, който оказва слабо съпротивление. От там въздухът отива в шестопътен кран и в зависимост от избраната позиция на последния въздухът преминава към съответната банка с ароматично вещество. Тук, преминавайки през дьлгата тръбичка, въздухът излиза на малки мехурчета от ароматичното вещество и адекватно количество ароматичен газ се отправя през двупътния кран към една от ноздрите на изследваното лице. Поради поддържането на по-висока температура $\left(30^{\circ} \mathrm{C}\right)$ в банките има добра изпаряемост на ароматичните субстанции и в зависимост от техния коефициент на летливост се осигурява един постоянен парен натиск. Тъй като цялата система на олфактометъра е затворена, поддържа се и постоянно количество ароматен газ в банките (400 $\left.\mathrm{cm}^{3}\right)$, който има постоянна концентрация и еднаква температура.

\section{Изследване на обонянието с олфактометьра на Димов-Райков}

Изследването на обонянието с олфактометьра на Димов-Райков става по следния начин. Включва се олфактометьрьт в електрическата мрежа. След няколко минути лампичката, показваща температурата $-\mathrm{t}^{\circ}$ - изгасва, което означава, че температурата в олфактометъра е достигнала $30^{\circ} \mathrm{C}$ и може да се започне работа. Изследваното лице поставя оливите на първия провод в носа (шестте арома- 
тични вещества имат самостоятелни проводи) (в нашето проучване използваме само 5). Задава се програма на олфактометъра: включва се първи канал чрез шестопътния кран, определя се количеството на ароматен газ с ръкохватката 1. Включва се кранчето 15 за една от ноздрите. Изследваното лице спира дишането и чрез пусковия бутон автоматично се изтласква определеният обем ароматично вещество. Пита се пациентьт дали усеща. По този начин се определя най-малкото количество, което предизвиква мирисно усещане. Така се установява относителният праг на обонянието и за срещуположната носна половина.

След определянето на прага на усещане се определя и прагът на разпознаване (идентификация). Подават се $20 \mathrm{~cm}^{3}$ ароматен газ надпрагово и се пита пациентът каква е миризмата на веществото. На олфактометъра има таблици с имената на миризмите на шестте ароматични вещества, подредени произволно. Изследваното лице трябва да посочи коя миризма е подадена. По този начин се изследват и останалите четири ароматични вещества по реда, по който са подредени в олфактометъра. Изследването на отделните вещества трябва да става с интервал повече от 30 секунди за една и съща половина на носа, за да се избегне повлияването на резултата от адаптационните феномени. Резултатите се нанасят на графики олфактограми за лява и дясна страна, по аналогия на аудиограмите. По този начин с олфактометъра на Димов-Райков едновременно с количественото изследване се извършва и качествено - определяме обонятелната спектрограма.

\section{Обонятелен скор}

В зависимост от стойностите на относителния праг на усет проф. Д. Димов разделя тежестта на хипосмията на четири степени - I, II, III и IV степен. За да направим пълна класификация на изследваните лица, ние въведохме още две групи: група 0 - пациенти със средни стойности на относителния праг в рамките на нормата и група 5 - пациенти със средни стойности на относителния праг над $40 \mathrm{~cm}^{3}$ - аносмици. По този начин получаваме следната класификация на преминалите олфактометричното изследване:

1 Група 0

2 І степен на хипосмия

3 II степен на хипосмия

4 III степен на хипосмия

5 IV степен на хипосмия

6 Група 5 нормосмици;

$$
\text { - } 10 \mathrm{~cm}^{3}
$$$$
\text { - } \quad \text { до } 20 \mathrm{~cm}^{3} \text {; }
$$$$
\text { - } \quad \text { до } 30 \mathrm{~cm}^{3} \text {; }
$$

- $\quad$ до $40 \mathrm{~cm}^{3}$;

- аносмици
При извършване на сертифицираното за РБългария обонятелно изследване класифицираме пациентите според обонятелните им способности за отделните ароматични вещества. За да можем обаче да направим цялостна оценка на обонянието на даден пациент за всички вещества едновременно, ние се нуждаем от количествена оценка на обонянието като цяло. Ръководехме се от следната логика: (1) На пациентите от група 0 (нормосмици) съпоставихме числото нула, тъй като те имат нормално обоняние; (2) С нарастването на степента на хипосмия числото, което съпоставяме, нараства с една единица - така I степен на хипосмия получава 1; II степен на хипосмия - 2; III степен на хипосмия - 3; IV степен на хипосмия - 4; Група 5 (аносмици) - 5; (3) Следователно колкото по-голямо е полученото число (индивидуална оценка), толкова обонянието за дадения одорант е по-лошо. За поголяма яснота отново даваме класификационната подредба със съответните числа, които им съпоставихме (табл. 1):

Таблица1. Количествена оценка на обонятелните способности на пациентите

\begin{tabular}{|l|l|l|}
\hline \multicolumn{1}{|c|}{$\begin{array}{c}\text { СТЕПЕН } \\
\text { ОБОНЯНИЕ }\end{array}$} & $\begin{array}{c}\text { ОтНОСИТЕЛЕН } \\
\text { ПРАГ }\end{array}$ & $\begin{array}{c}\text { индивиду- } \\
\text { ална коли- } \\
\text { чествена } \\
\text { оценка }\end{array}$ \\
\hline нормосмия & $\leq 8 \mathrm{~cm}^{3}$ & 0 \\
\hline хипосмия I степен & $9-11 \mathrm{~cm}^{3}$ & 1 \\
\hline хипосмия II степен & $12-20 \mathrm{~cm}^{3}$ & 2 \\
\hline хипосмия III степен & $21-30 \mathrm{~cm}^{3}$ & 3 \\
\hline хипосмия IV степен & $31-40 \mathrm{~cm}^{3}$ & 4 \\
\hline аносмия & $>40 \mathrm{~cm}^{3}$ или $0 \mathrm{~cm}^{3}$ & 5 \\
\hline
\end{tabular}

Таблица 2. Въвеждане на обонятелен скор за цялостна оценка на обонятелните способности

\begin{tabular}{|c|c|c|c|}
\hline $\begin{array}{c}\text { СТЕПЕН НА ОБО- } \\
\text { НЯНИЕ }\end{array}$ & $\begin{array}{l}\text { ОТНОСИТЕ- } \\
\text { ЛЕН ПРАГ }\end{array}$ & 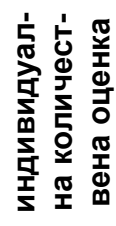 & $\begin{array}{c}\text { ОБО- } \\
\text { НЯТЕ- } \\
\text { ЛЕН } \\
\text { СКОР }\end{array}$ \\
\hline нормосмия & $\leq 8 \mathrm{~cm}^{3}$ & 0 & $0-4$ \\
\hline хипосмия I степен & $9-11 \mathrm{~cm}^{3}$ & 1 & $5-9$ \\
\hline хипосмия II степен & $12-20 \mathrm{~cm}^{3}$ & 2 & $10-14$ \\
\hline хипосмия III степен & $21-30 \mathrm{~cm}^{3}$ & 3 & $15-17$ \\
\hline хипосмия IV степен & $31-40 \mathrm{~cm}^{3}$ & 4 & $18-20$ \\
\hline аносмия & $\begin{array}{l}>40 \mathrm{~cm}^{3} \text { или } \\
0 \mathrm{~cm}^{3}\end{array}$ & 5 & $>20$ \\
\hline
\end{tabular}

Обобщената оценка за всички вещества за даден пациент (обонятелен скор) се получава, като съберем отделните стойности на индивидуалните оценки за отделните одоранти.

Следователно комбинираната оценка на нормосмика трябва да бъде нула или близка до нула, дока- 
то на аносмика оценката е близка до 25 (защото приемаме, че се оценява обонянието на по-добрата ноздра, подобно на оценката на слуха - пълната липса на слух в едното ухо не дава $50 \%$ намаление на слуха).

\section{Заключение}

През 1991 г. Линда Бук и Ричард Аксел откриха заедно семейство на трансмембранни белтъци, за които се вярваше, че представляват мирисни рецептори. Те установиха също така и някои от гените, които ги кодират. Бук и Аксел клонираха и характеризираха 18 различни представители на едно изключително огромно мултигенно семейство, кодиращо белтъци със седем трансмембранни домена, и чиято експресия е ограничена единствено в обонятелния епител. Чрез методите на генното клониране Линда Бук и Ричард Аксел категорично доказаха наличието на обонятелни рецептори в обонятелната лигавица на човека. Нещо повече - те поставиха основите на изучаването на механизмите за кодиране на обонятелната

\section{Литература:}

1. Amoore, J.E. Molecular Basis of Odor, C.C. Thomas, Pub., 1970 Springfield.

2. Dyson, G. M. The Scientific Basis of Odor, 1938 Chem. Ind., No 57 : 647-651.

3. Kuhl, P. W. A redox cycling model for the action of beta-adrenoceptor agonists, 1985, Experientia, No 41 : 1118-22.

4. Langenau, E. E., Olfaction and Taste, 1967, Vol. III., C. Pfaffman, Ed., Rockefeller University Press, New York.

5. Leffingwell, J. C. comment in Gustation and Olfaction, 1971, G. Ohloff and A. Thomas, Ed., Academic Press, NY, p. 144.

6. Malnic, B., J. Hirono, T. Sato, L. B. Buck. Combinatorial receptor codes for odors. 1999, Mar 5, Cell, Vol. 96, No 5 : 713-23.

7. Moncrieff, R.W. What is Odor. A New Theory, 1949, Am. Perfumer, 54: 453.

8. Pauling, L. Molecular architecture and Biological Reactions, 1946, Chem. Eng. News, Vol. 24, No 1375; цитирано от Ohloff, G., Scent and Fragrances, 1994, Springer-Verlag, Berlin Heidelberg. информация, които започват още на нивото на обонятелните луковици. За своите достижения в областта на обонянието двамата учени си поделиха Нобеловата награда за медицина за 2004 г. Техните открития направиха пробив в нашите разбирания за обонятелната система. Тъй като обонятелното възприятие е в състояние да диференцира хиляди различни одоранти, на практика е невъзможно то да се оцени с няколко прости теста. В зависимост от нужната информация могат да се използват различни тестове, които да измерват различни страни на обонятелната система. За нуждите на клиничната практика, обаче, подобно диверсифициране на тестовете е неудобно, но за наша радост изследването на обонянието с олфактометъра на Димов-Райков наистина позволява да се определи обонятелната спектрограма на изследваните лица. Предложената от нас цялостна оценка на обонянието позволява с едно число да се представят множеството аспекти на това често неглижирано сетиво - обонянието.
9. Rodriguez, I., C. A. Greer, M. Y. Mok, P. Mombaerts. A putative pheromone receptor gene expressed in human olfactory mucosa, 2000, Sep, Nat Genet, Vol. 26, No 1: 18-9

10. Rubin, B. D., L. C. Katz. Spatial coding of enantiomers in the rat olfactory bulb, 2001, Apr, Nat Neurosci, Vol. 4, No 4: 355-6.

11. Savic, I., H. Berglund, B. Gulyas, P. Roland. Smelling of odorous sex hormone-like compounds causes sex-differentiated hypothalamic activations in humans, 2001, Aug 30,Neuron, Vol. 31, No 4: 661-8.

12. Turin, L. A spectroscopic mechanism for primary olfactory reception. 1996, Chem. Senses, No 21: 773-791. /33/ (Leffingwell)!

13. Wood, W. B., et.al. Editors, Biochemistry A Problems Approach, , W. A. Benjamin, Inc., p. 195.

14. Wright, R. H. The Sense of Smell, 1982, CRC Press, Boca Raton, $155-$ 156.

15. Zhao, H., S. Firestein, C. A. Greer. NADPH-diaphorase localization in the olfactory system. 1994, Neuroreport., Vol. 6, No 1: 149-52. 